\title{
Thoughts on rural energy structure adjustment and construction of digital city of Chinese Capital in Beijing
}

\author{
WANG ZHI ${ }^{1^{*} \mathbf{a}}$, Zi-hua GUO ${ }^{2, b}$ \\ ${ }^{1}$ Institute of Agricultural Integrated Development, Beijing Agriculture and Forestry Academy of \\ Science, Beijing 100097 \\ ${ }^{2}$ Beijing Municipal Rural Work Committee, Beijing 100083 \\ ${ }^{*}$ Corresponding author: angelwang1009@163.com
}

Keywords: Beijing city; New rural construction; Rural energy; Rural sewage treatment; Digital City

\begin{abstract}
In recent years, the Beijing construction in accordance with the philosophy of environmental protection, solid depth to carry out a series of policies and measures, such as rural energy structure optimization and adjustment; rural residential seismic energy-saving; village green landscaping. If displaying and recording movement states and regulars of the beautiful countryside construction through this information process, It will greatly strengthen regulation of the relationship between new rural people, to realize system optimization, make urban and rural become conducive to human survival and sustainable development of space.
\end{abstract}

\section{Introduction}

Digital City is the use of spatial information to build virtual platforms, including urban natural resources, social resources, infrastructure, cultural, economic and other information about the city, in order to obtain and load up the digital form, so as to provide a wide range of aspects of government and society service. Through advanced means of information, support Beijing new rural planning, construction, operation, management and emergency, can effectively improve the government management and service levels, improve the new rural management efficiency, conserve resources, promote the development of the beautiful countryside.

\section{Beautiful countryside construction is an important basis for the construction of ecological civilization and beauty of China}

Chinese capital of Beijing, an area of 16,400 square kilometers in rural areas accounted for 1.5 million square kilometers, if rural development is not good, ecological Beijing will be no barrier, there will be no space environment, and sustainable development will be on the lack of foundation.

\section{Major policies and measures to promote the construction of beautiful countryside}

We recognize the importance and urgency of the beautiful countryside construction, but also, perceive that the complexity and difficulty to build a beautiful countryside. In recent years, Beijing launched a series of livelihood projects., including farmhouse seismic energy-saving projects, risk village and insurance households from mountain relocation project, Clean Air Initiative in rural areas reducing coal, Agricultural non-point source pollution control projects, Rural Ecological Environment Construction Engineering, and so on, rural environment continues to improve, rural 
infrastructure and public service facilities gradually improved, the rural energy structure was further optimized, farmer housing conditions and income levels are rising. New Rural Construction of Beijing has been built a beautiful countryside and laid a good foundation. At the same time we should also see that although the new rural construction of Beijing has made remarkable achievements, yet, with the urgent needs of the majority of farmers, and the requirements of building world-class city, there is still a big gap, but also need to be improved in the following areas.

\section{Rural energy structure adjustment and optimization.}

In recent years, the Beijing government has been to actively promote the use of new energy sources, new technologies in rural areas, and started to implement the " Reducing Coal and Replaced Coal, Clean air" Initiative. Preliminary accounting, in 2013 heating season, the Beijing rural areas completed 2954 tons of sulfur dioxide emissions, nitrogen oxides 3512 tons emissions, and 7397 tons of carbon dioxide emissions, accounting for $22 \%$ of the city's rural areas, 4.3 million tons of total coal-fired. but there are still nearly $80 \%$ of farmers are still using low-grade coal, as well as a large number of public facilities in rural areas, enterprises and institutions were not clean energy transformation. Therefore, we should continue to promote the rural areas "Reducing Coal and Replaced Coal, Clean air" Initiative. Through the joint action of government, market and society, at a rate of about 1 million tons per year, with a further three years to complete rural clean alternative, while by replacing heating coal to electricity, sending natural gas to home, as well as using liquefied petroleum gas, appliances solar, biomass, air energy, geothermal energy utilization, etc., to realize gasification of rural areas for cooking, heating and clean.

\section{Rural Residential Seismic energy-saving projects.}

Since at 2007, Beijing started Farmhouse seismic energy-saving projects, it has supported 380,000 rural residents in the implementation of energy-saving residential earthquake. Through the implementation of seismic energy-saving projects, farmers housing winter indoor temperature has increased by 4 to 6 degrees, saving more than $30 \%$ of coal-fired. In summer, obviously feeling the cool interior, indoor temperature is relatively low outside temperatures 5 to 6 degrees. According to statistics, only this thermal insulation, has an annual saving of coal-fired nearly 55 million tons, a significant reduction in carbon dioxide emissions, effectively improve air quality. According to surveys, there are still 530,000 rural residents in Beijing have seismic energy-saving requirements. Therefore, to further increase the Farmhouse seismic energy-saving efforts, using of 5 years, at a rate of about 100,000 a year, it will complete the city's Farmhouse seismic energy-saving task.

\section{Sewage treatment works in rural areas.}

In recent years, new rural construction in Beijing, more than 500 villages have been built sewage treatment facilities in 1010, but due to complex process, facilities scattered layout, unfocused, factory network is not complete, the high cost of operation and maintenance, management operation is not in place and other reasons, rural sewage treatment facilities, $30 \%$ did not run or intermittent operation. In beijing rural area, annual output of sewage is more than 100 million tons, but, treatment rate is only about 50\%. large amounts of sewage is discharged directly. With the rapid development of urbanization and rural economic and social, supply and demand contradictions in rural city sewage treatment facilities have become increasingly prominent. Therefore, the reality requires us to rural sewage treatment as an important part of the construction of the beautiful countryside. For facilities that have been built to run on to assess the situation, according to local conditions to transform and strengthen the operation and maintenance, and ensure that the newly built sewage treatment facilities operating normally, the basic objectives of rural sewage discharge standards may successfully achieve in 2020. 


\section{Thoughts on promoting Digital City and the construction of beautiful countryside}

In the capital, to promote the digital city construction process, the author has deeply thinking for digital villages and beautiful countryside construction as follows:

First, the establishment of Beijing rural information service platform and the beautiful countryside of information resource library. It will cover many aspects of rural infrastructure, rural economy, industry characteristics, population health, culture, education, grass-roots organizations and other resources for effective integration of information and data, and establish a cover Beijing, connecting Beijing, Tianjin city, county, township and village "digital village" information network platform.

The second is the establishment of "Beijing Digital Village" platform, its function should have a strong practical and advanced. It can form in a variety of vivid visual image, data, icons and text, etc., it can provide information on all aspects of rural work for the government at all levels in Beijing, so as to provide a reliable basis for the scientific and democratic decision-making of new rural construction. Beautiful countryside construction in every measure can be demonstrated and information management, the establishment of relevant information platform. Moreover, with the continuous improvement platform, which will provide reliable first-hand information for all agricultural sectors and investment units, it lay a solid foundation for the economic development of Beijing Rural Development and Investment, the same time, the Present Situation can be shown by the platform the beautiful countryside as a window, it can be to promote the rural areas this emerging e-commerce business model, so as to promote the exchange of agricultural products and accelerate rural economic development has laid a good foundation.

Third, pay attention to the establishment of several information platform, focusing on people's livelihood and ecological protection. The main measures "optimal adjustment of rural energy structure, agricultural nonpoint source pollution control, rural residential seismic energy-saving projects, sewage treatment works in rural areas" and other beautiful countryside construction are to be monitored and managed through the information platform to maximize for the construction of ecological civilization provide effective protection, as well as the national new rural construction to enhance digital play a leading and exemplary role.

\section{Acknowledgement}

This research was financially supported by the Beijing Municipal Rural Work Committee Technology Services Special Fund.

\section{References}

[1] Meng xiang-lin.Strategic studying for Tangshan City's economic integeration in JingJinJi region based on "Double Parents+Double Sons" theory[J]. CITY, 2011 ( 4 ) .

[2] HE Ling, WANG Jun,DONG qian. Agricultural development model of regional economic integration of Beijing City, Tianjin City and Hebei Province[J]. JIANGSU AGRICULTURAL SCIENCES, 2011, 39(2).

[3] WANG Zhi, ZHOU Lian-di, LIU Shi-rong, et al. The Effect on Abating Pollution from Farmland Runoff by Using Biogas Manures[J]. JOURNAL OF ANHUI AGRICULTURAL SCIENCES, 2009, 37(10).

[4] CHEN Zhang, YAN Ping, SHAO Wei. Beijing, Tianjin Economic Contacts[M].DATA, 2011, (3). 
[5] Digital City Network. http://www.4d3s.com/

[6] http://baike.baidu.com/view/2282762.htm.

[7] Yang X, Jiang Y, Yang M, et al. Energy and environment in Chinese rural housing: Currentstatus and future perspective. Front. Energy Power Eng. China 2010, 4(1): 35-46.

[8] Ho-Lin H, Murray M, Cohen T, Colijn C, et al. Effects of smoking and solid-fuel use on COPD, lung cancer,and tuberculosis in China: a time-based, multiple risk factor, modeling study. Lancet, 2008, 372:1473-1483.

[9] Al-Homoud M S. Performance characteristics and practical applications of common building thermal insulation materials. Building and Environment, 2005, 40: 353-366.

[10] Omakli K, Yuksel B.Optimum insulation thickness ofexternal walls for energy saving. Applied Thermal Engineering,2003,23:473-479.

[11] Erlandsson M. Energy and environmental consequences of an additional wall insulation of a dwelling. Building andEnvironment,1997,32(2):129-136.

[12] Ahmad.A, Saini JS, Varma HK. Effect of geometrical and thermophysical characteristics of bed materials on the enhancement of thermal performance of packed bed solar air heaters. Energy Conversion and Management, 1995, 36(12): 1185-1195.

[13] Hegazy AA. Performance of flat plate solar air heaters with optimum channel geometry for constant/variable flow operation. Energy Conversion and Management,2000, 41(4):401-417.

[14] Varol Y, Oztop HF. A comparative numerical study on natural convection in inclined wavy and flat-plate solar collectors. Building and Environment, 2008, 43(9): 1535-1544.

[15] Varol Y, Oztop HF. Buoyancy induced heat transfer and fluid flow inside a tilted wavy solar collector. Building and Environment, 2007, 42(5): 2062-2071.

[16] Shaeri MR, Yaghoubi M. Thermal enhancement from heat sinks by using perforated fins, 2009, 50: $1261-1270$. 